\title{
CONTRATO DE REPRESENTAÇÃO COMERCIAL
}

\section{BUSINESS REPRESENTATION AGREEMENT}

\section{GISELE BOLONHEZ KUCEK}

Mestranda em Direito Empresarial e Cidadania pelo Centro Universitário Curitiba UNICURITIBA. Curitiba - PR, Especialista em Direito Processual Civil pelo Instituto de Direito Romeu Felipe Bacellar (2008). Bacharel em Direito pela Universidade Federal do Paraná - UFPR (2006). Advogada. E-mail: gisele.bolonhez@gmail.com

\section{ANDRÉ LIPP BASTO LUPI}

Professor Orientador - Centro Universitário Curitiba - UNICURITIBA. Curitiba - PR. E-mail: andre@mnadvocacia.com.br

\section{RESUMO}

O contrato de representação comercial é um dos meios mais utilizados no âmbito empresarial para comercialização de um produto ou serviço no mercado. É regulamentado pela Lei ํㅜ 4.886/65, com as modificações inseridas pela Lei $n^{\circ}$ 8.420/92. Através deste tipo de contrato as empresas não precisam despender recursos na criação de filiais próprias, o que viabiliza a comercialização em novas regiões a custos mais baixos, além da facilidade de contratar através de um representante que conheça as peculiaridades daquela região. Contudo, em que pese ser um dos contratos mais empregados, tem sido comum a propositura de demandas perante a Justiça do Trabalho com o intuito de desconstituí-los em decorrência da comprovação dos elementos de uma relação de emprego, caso em que as empresas são obrigada a suportar os encargos decorrentes de tal reconhecimento. Surge então uma zona de conflito entre o contrato de representação comercial e a relação de 
Personalidade Acadêmica Homenageada:

Augustus B. Cochran III (Agnes Scott College)

emprego. Para a realização da pesquisa será utilizado o método teórico-bibliográfico, abordando-se o tema através de métodos dedutivos-dialéticos. A partir da análise do entendimento jurisprudencial dos Tribunais Superiores é possível afirmar que o contrato de representação possui natureza empresarial, no qual, ainda que exista interdependência entre as partes (representante e representado), a fim de que o objeto do contrato de concretize em benefício de ambos, vigora a autonomia essencial ao exercício da atividade do colaborador. As obrigações devem ser previamente pactuadas, estabelecendo-se as condições em que a atividade será desenvolvida, tais como exclusividade, modo e pagamento das remunerações e zona de atuação do representante, sob pena de, em não estando adequadamente estabelecidas as regras, o representado ser obrigado ao pagamento da remuneração sobre todos os negócios por ventura realizados em desacordo com o pactuado. Eventual desvirtuamento deste contrato com o intuito de mascarar relação de emprego tem sido afastado pela jurisprudência através do reconhecimento do vínculo e condenação ao pagamento das verbas trabalhistas.

PALAVRAS-CHAVE: Contrato de Representação; Contrato de Trabalho; Conflito.

\section{REFERÊNCIAS}

MENDONÇA, Vinícius de Carvalho P. O contrato de representação comercial na visão dos tribunais superiores brasileiros. Revista da Faculdade de Direito da Universidade Federal de Minas Gerais, Belo Horizonte, MG, n.62, p. 657 - 701, jan./jun. 2013.

SÜSSEKIND, Arnaldo. Da relação de Trabalho. Revista do Tribunal Superior do Trabalho, Brasília, DF, v. 75, oㅡ 4, p. 17 - 24, out./dez. 2009.

PEREIRA JUNIOR, Antonio Jorge; SANTOS, Ivanna Pequeno dos. Boa-fé objetiva nos contratos empresariais: o Caso da CIA Nacional de Tecidos de Juta. Revista Jurídica UNICURITIBA, Curitiba, PR, v. 52, n. 3, p. 68 - 85, jul./set. 2018. 